\title{
Effect of ultra-high hydrostatic pressure on the survival of Chromohalobacter beijerinckii
}

\author{
JANINA PĘCONEK, MONIKA FONBERG-BROCZEK*, \\ JACEK SZCZAWIŃSKI, DOROTA SAWILSKA-RAUTENSTRAUCH**
}

\author{
Department of Food Hygiene and Public Health, Faculty of Veterinary Medicine, \\ Warsaw University of Life Sciences - SGGW, Nowoursynowska 159, 02-776 Warsaw, Poland \\ *Institute of High Pressure Physics, Polish Academy of Sciences, Sokołowska 29, 01-142 Warsaw, Poland \\ **Department of Food and Consumer Articles Research, \\ National Institute of Public Health - National Institute of Hygiene, Chocimska 24, 00-791 Warsaw, Poland
}

Pęconek J., Fonberg-Broczek M., Szczawiński J., Sawilska-Rautenstrauch D. Effect of ultra-high hydrostatic pressure on the survival of Chromohalobacter beijerinckii

Summary

The aim of the study was to determine the effect of ultra-high hydrostatic pressure on the survival of Chromohalobacter beijerinckii in samples of nutrient broth containing a $6 \%$ addition of $\mathrm{NaCl}$ and in samples of cold-smoked salmon. Both types of samples were exposed to ultra-high hydrostatic pressure of 300 and $400 \mathrm{MPa}$ for $0,5,10$ and $15 \mathrm{~min}$. The number of Chromohalobacter beijerinckii was determined in all control samples and samples subjected to high pressure. The total number of aerobic bacteria was additionally determined in the samples of cold-smoked salmon intentionally inoculated with Chromohalobacter beijerinckii. It was found that Chromohalobacter beijerinckii showed a clearly greater sensitivity to high hydrostatic pressure in the nutrient broth (D-values: $300 \mathrm{MPa}-3.72 \mathrm{~min} ; 400 \mathrm{MPa}-1.90 \mathrm{~min}$ ) than it did in the samples of cold-smoked salmon (D-values: $300 \mathrm{MPa}-5.83 \mathrm{~min} ; 400 \mathrm{MPa}-3.08 \mathrm{~min}$ ). The results concerning the total number of aerobic bacteria show that Chromohalobacter beijerinckii is more susceptible to high pressure than the accompanying microflora present in cold-smoked salmon. High pressure treatment at $400 \mathrm{MPa}$ applied for $\mathbf{1 5}$ min caused a destruction of Chromohalobacter beijerinckii cells that was clearly visible under a scanning electron microscope. Chromohalobacter beijerinckii belongs to bacteria that have average sensitivity to high hydrostatic pressure.

Keywords: HPP, Chromohalobacter beijerinckii, food safety, inactivation of microorganisms

Studies on the role of halophilic bacteria in the process of histidine decarboxylation in fish muscles $(15,22)$ have been carried out at the Department of Food Hygiene and Public Health, Faculty of Veterinary Medicine, since 1991. As part of these studies, strains of halophilic bacteria were isolated from salted herrings, and their ability to produce histamine by decarboxylation of histidine was proved under model conditions according to the method described by Karnop (12). Our own modification consisted of an increased amount of $\mathrm{NaCl}$ added to the nutrient broth. It was revealed that all bacteria isolated from herrings are able to multiply and produce histamine in an environment containing both $8 \%$ and $20 \% \mathrm{NaCl}(2,17,18,21)$. Out of the isolated halophilic bacteria, one strain, marked as strain $3 \mathrm{~b}$, had an exceptionally high ability to produce histamine by decarboxylation of histidine $(3,21)$. Strain $3 \mathrm{~b}$ was counted among the Pseudomonas beijerinckii species, isolated for the first time from salted beans by Hof in 1935 (10). The reference strain of Pseudomonas beijerinckii $\left(\right.$ type strain DSM $7218^{1}=$ ATCC $19372^{\mathrm{T}}=$ NCIMB 9041') and strain 3b were subjected to more detailed investigations. The analysis of the 16S rRNA gene sequences, phenotypic properties, and similarities in the composition and profile of fatty acids pointed to both strains (reference and $3 \mathrm{~b}$ ) belonging to the same genus Chromohalobacter, family Halomonadaceae (1). In view of the results obtained, it seemed appropriate to reclassify Pseudomonas beijerinckii and recognize it as Chromohalobacter beijerinckii (20).

Chromohalobacter beijerinckii strain $3 \mathrm{~b}$ belongs to the psychrophilic bacteria, which can grow at temperatures between $5^{\circ} \mathrm{C}$ and $42^{\circ} \mathrm{C} \mathrm{(20)} \mathrm{and} \mathrm{with} \mathrm{a} \mathrm{NaCl}$ content of $0.5 \%$ to $25.0 \%$, and which tolerate a $\mathrm{pH}$ value between 4.5 and 8.0. The presence of salt is a factor that determines both the growth of that strain and its 
proteolytic (17) and lipolytic (19) activity, as well as its ability to decarboxylate lysine, tyrosine, and histidine $(2,20)$. During the growth of Chromohalobacter beijerinckii in salted fish stored under cooling conditions, the biogenic amines, especially histamine and tyramine, as well as putrescine and cadaverine may appear and accumulate $(2,3,6,18)$.

The properties of Chromohalobacter beijerinckii attracted interest from researchers all over the world $(4,9,21)$. Although strain $3 \mathrm{~b}$ is not a pathogen, it can be a microbiological risk factor during the storage of salted fish, especially in fish rich in histidine, as demonstrated in experimental studies $(2,4,6,9)$.

A modern and promising method for inactivating pathogenic bacteria in food products, while preserving their organoleptic properties, is high pressure pasteurization $(5,7,8,11,13,23-26)$.

The aims of the present study were to determine the effect of ultra-high hydrostatic pressure on

- the survival of Chromohalobacter beijerinckii under various environmental conditions, i.e. in samples of an enriched nutrient broth containing $6 \% \mathrm{NaCl}$ and in cold-smoked salmon samples,

- the total number of aerobic bacteria in cold-smoked salmon samples,

- morphological changes in Chromohalobacter beijerinckii cells.

\section{Material and methods}

Samples for pressure treatment were prepared from a Chromohalobacter beijerinckii culture in an enriched nutrient broth containing the addition of $6 \% \mathrm{NaCl}$ and incubated at $30^{\circ} \mathrm{C}$ for $72 \mathrm{~h}$. Since the packaging of products subjected to pressure treatment has to be tight as well as flexible and resistant, $2 \mathrm{ml}$ polypropylene microtest-tubes (by Sarstedt) with a screw top and "o-ring" sealing were used.

The material used for the study comprised a $72 \mathrm{~h}$ culture of Chromohalobacter beijerinckii in a nutrient broth with $6 \% \mathrm{NaCl}$ and in cold-smoked salmon bought at a local store.

Ten-gram samples of salmon were inoculated with a $72 \mathrm{~h}$ Chromohalobacter beijerinckii culture in nutrient broth with $6 \% \mathrm{NaCl}$ at $30^{\circ} \mathrm{C}$ (inoculum ca $10^{7} / \mathrm{g}$ ) and hermetically sealed in packages made of polyamide-polyethylene foil (Multiseven 78 TOP, Wipak $^{\circledR}$ ) by means of a vacuum sealing appliance Hencovac ${ }^{\mathbb{B}} 1000$. The samples were exposed to high-pressure treatment at the Institute of High Pressure Physics, Polish Academy of Sciences, where a special stand for food testing had been built: a high pressure food processor piston-cylinder type vessel with an inner diameter of $110 \mathrm{~mm}$, working volume of $1.5 \mathrm{l}$, and a maximum pressure of $700 \mathrm{MPa}$, equipped with an internal heat exchanger and a thermocouple located in the middle of the vessel. Hydrostatic pressure inside the chamber is measured indirectly by means of a pressure gauge, a strain gauge pressure transducer (KGT Kramer), and a Bourdon type manometer, indicating the pressure under the piston rod. The pressure and temperature sensors are linked to a Computer Data Acquisition System (Memory Card MMC). This equipment is capable of analysing the variation of temperature in relation to pressure. The pressure-transmitting medium used is a mixture of distilled water and propylene glycol $(1: 1)$. The working pressure $(200,300$ and $400 \mathrm{MPa})$ was generated in 15-20 s, and the release time was $15 \mathrm{~s}$. The variation in temperature in the high pressure vessel during pressurisation is about $2^{\circ} \mathrm{C}$.

The number of Chromohalobacter beijerinckii was determined in all the samples, both control and experimental. Series of tenfold dilutions were prepared from specific samples, and inoculations were then performed on plates with nutrient agar with the addition of $6 \% \mathrm{NaCl}$. The plates were incubated at $30^{\circ} \mathrm{C}$ for $72 \mathrm{~h}$.

The total number of aerobic bacteria was also determined in samples of smoked salmon intentionally inoculated with Chromohalobacter beijerinckii. Tenfold dilutions were made, and $0.5 \mathrm{ml}$ of dilution was spread onto nutrient agar (without the addition of $\mathrm{NaCl}$ ). The plates were incubated at $30^{\circ} \mathrm{C}$ for $72 \mathrm{~h}$.

The experiment was repeated three times. The colonies on the plates were counted, and the final result was presented as the colony-forming units calculated per $1 \mathrm{~g}$ of muscle tissue. The bacterial counts were transformed into logarithms and analyzed statistically with the use of general linear models provided by PASW Statistics 18 Edition 18.0.0.

The D-value (time in minutes necessary for a tenfold reduction in the number of bacteria, i.e. one log unit) was determined by the linear regression method.

From the control and pressurized bacterial cultures, $5 \mu \mathrm{l}$ samples were taken for examination under a scanning electron microscope. The samples were mounted onto a conductive table covered with a carbon band, dried for $3 \mathrm{~h}$ at $20^{\circ} \mathrm{C}$, and covered with a thin gold layer by a Vacuum Evaporator JEE-4C, JEOL, Japan. The samples were observed by means of a scanning electron microscope Quanta 200, Czech Republic.

\section{Results and discussion}

The results presented in Fig. 1 indicate that the HP treatment of the $72 \mathrm{~h}$ culture of Chromohalobacter beijerinckii in the nutrient broth containing $6 \% \mathrm{NaCl}$

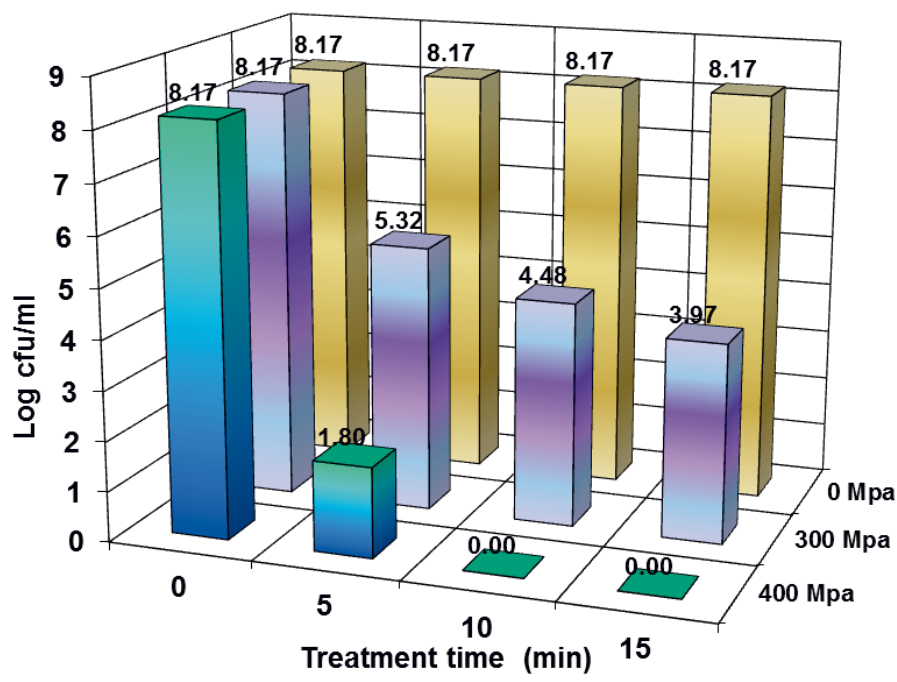

Fig. 1. Effect of the pressure value and treatment time on the number of Chromohalobacter beijerinckii $3 \mathrm{~b}$ in nutrient broth containing $6 \% \mathrm{NaCl}$ 


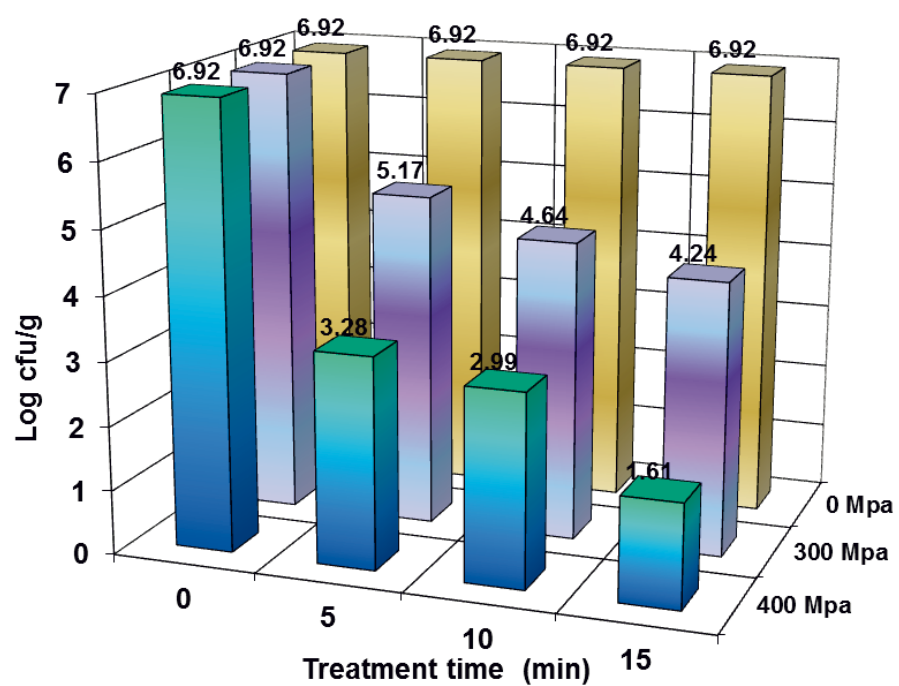

Fig. 2. Effect of the pressure value and treatment time on the number of Chromohalobacter beijerinckii $3 \mathrm{~b}$ in smoked salmon

reduced the number of the microorganisms, and the reduction increased with increasing pressure and treatment time. A significant decrease in the number of Chromohalobacter beijerinckii cells was observed in samples subjected to a pressure of $300 \mathrm{MPa}$ for $5 \mathrm{~min}$ - reduction by $2.85 \mathrm{log}$. Prolonging treatment time to 10 and 15 min resulted in a reduction of 3.69 and 4.2 $\log$, respectively. A significant reduction, by $6.37 \mathrm{log}$, was observed after applying a pressure of $400 \mathrm{MPa}$ for $5 \mathrm{~min}$. No growth of Chromohalobacter beijerinckii was observed after a pressure of $400 \mathrm{MPa}$ had been applied for 10 and $15 \mathrm{~min}$.

Changes in the number of Chromohalobacter beijerinckii in the samples of cold-smoked salmon are presented in Fig. 2.

At a pressure of $300 \mathrm{MPa}$, reduction was the smallest, amounting to $1.75 \mathrm{log}$ after $5 \mathrm{~min}$. Prolonging the time to 10 and $15 \mathrm{~min}$ decreased the count of Chromohalobacter beijerinckii in cold-smoked salmon by 2.28 and $2.68 \mathrm{log}$, respectively. Treating the samples with $400 \mathrm{MPa}$ for 5,10 , and $15 \mathrm{~min}$ reduced the number of the microorganisms by $3.64,3.93$, and $5.31 \mathrm{log}$, respectively.

The results presented in Fig. 2 demonstrate that the Chromohalobacter beijerinckii population in vacuum-packed smoked salmon was clearly more resistant

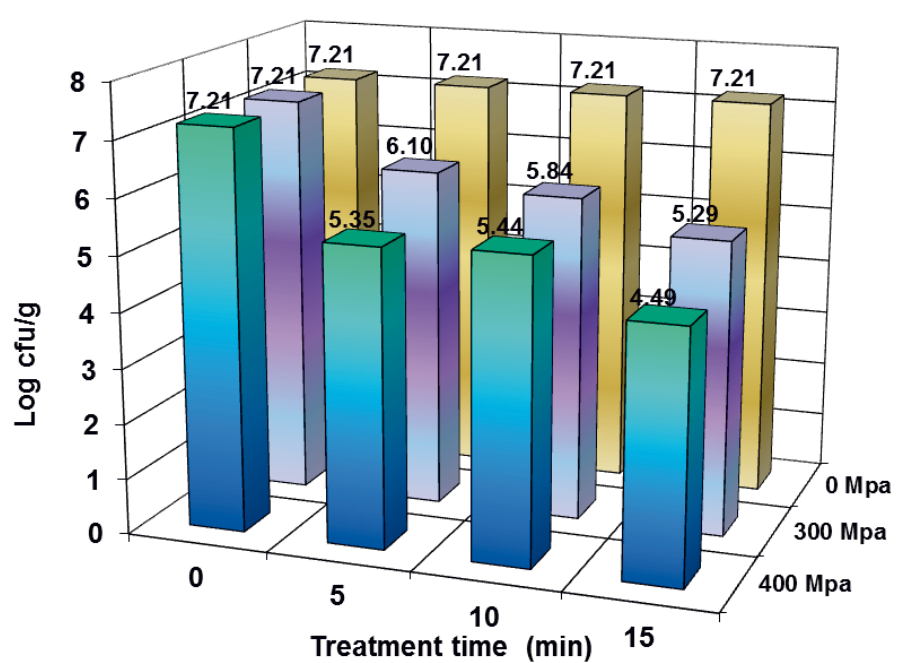

Fig. 3. Effect of high-pressure treatment on the total plate count in samples of smoked salmon inoculated with $C$. beijerinckii 3b

to high hydrostatic pressure treatment than that in the nutrient broth with $6 \% \mathrm{NaCl}$.

The results presented in Fig. 3 show that the total number of living aerobic bacterial cells in the control samples was $7.21 \log \mathrm{cfu} / \mathrm{g}$. After subjecting them to $300 \mathrm{MPa}$, the number of bacteria decreased slightly with increased pressure time, by $1.11,1.37$, and 1.92 $\log$, respectively. After applying a pressure of $400 \mathrm{MPa}$ for 5,10 , and $15 \mathrm{~min}$, reductions of $1.87,1.77$, and 2.72 $\log$, respectively, were observed. A comparison of the results in Fig. 2 and Fig. 3 indicates that the accompanying microflora present in cold-smoked salmon is much more resistant to high hydrostatic pressure than C. beijerinckii.

Linear regression equations describing relationships between the number of bacteria and treatment time in various experimental groups, as well as D-values calculated from these equations, are presented in Tab. 1.

The time needed for a decimal reduction in the number of Chromohalobacter beijerinckii in the samples of smoked salmon treated with $300 \mathrm{MPa}$ was longer by $2.11 \mathrm{~min}$ than the $\mathrm{D}$-value for the samples of the nutrient broth containing $6 \% \mathrm{NaCl}$. In the samples treated with $400 \mathrm{MPa}$, the difference in the D-value was $1.18 \mathrm{~min}$ (Tab. 1). It may be explained by the different chemical composition of the two kinds of

Tab. 1. D-values - time required for a decimal reduction in bacterial population

\begin{tabular}{|c|c|c|c|c|c|c|}
\hline \multirow{2}{*}{ Microorganism and environment } & \multirow{2}{*}{$\begin{array}{l}\text { Pressure } \\
\text { value }[\mathrm{MPa}]\end{array}$} & \multirow{2}{*}{$\begin{array}{l}\text { Linear regression } \\
\text { coefficient (b) }\end{array}$} & \multirow{2}{*}{$\begin{array}{l}\text { D-value }(-1 / b) \\
\text { [min] }\end{array}$} & \multicolumn{2}{|c|}{$\begin{array}{l}\text { 95\% confidence intervals for } \\
\text { D-value [min] }\end{array}$} & \multirow{2}{*}{$\begin{array}{l}\text { Correlation } \\
\text { coefficient (r) }\end{array}$} \\
\hline & & & & Lower limit & Upper limit & \\
\hline \multirow{2}{*}{$\begin{array}{l}\text { Chromohalobacter beijerinckii } 3 \mathrm{~b} \text { in nutrient broth } \\
\text { with } 6 \% \mathrm{NaCl}\end{array}$} & 300 & -0.269 & 3.72 & 2.86 & 5.31 & -0.920 \\
\hline & 400 & -0.526 & 1.90 & 1.34 & 3.26 & -0.860 \\
\hline \multirow{2}{*}{$\begin{array}{l}\text { Chromohalobacter beijerinckii 3b in smoked } \\
\text { salmon }\end{array}$} & 300 & -0.172 & 5.83 & 4.52 & 8.18 & -0.926 \\
\hline & 400 & -0.325 & 3.08 & 2.30 & 4.67 & -0.901 \\
\hline \multirow{2}{*}{$\begin{array}{l}\text { Total microbial count in smoked salmon } \\
\text { inoculated with Chromohalobacter beijerinckii } 3 \mathrm{~b}\end{array}$} & 300 & -0.120 & 8.33 & 6.75 & 10.86 & -0.949 \\
\hline & 400 & -0.161 & 6.20 & 4.69 & 9.12 & -0.910 \\
\hline
\end{tabular}


samples. According to the information on the label of the cold-smoked salmon, the product contained $19.3 \mathrm{~g}$ protein and $9.9 \mathrm{~g}$ fat for every $100 \mathrm{~g}$ of muscle tissue. Protective effects of protein and fat on the survival of bacteria in samples of food subjected to high pressure were also observed in our previous studies (24).

The total number of aerobic bacteria in the samples of smoked salmon subjected to high pressure treatment decreased to a lesser degree than the number of Chromohalobacter beijerinckii, but the extent of the reduction observed was large enough to improve the quality and microbial safety of fish and to prolong its shelf-life.

Photographs taken under an electron microscope (SEM) and presented in Fig. 4 and Fig. 5 show noticeable differences in the shape of a control Chromohalo-
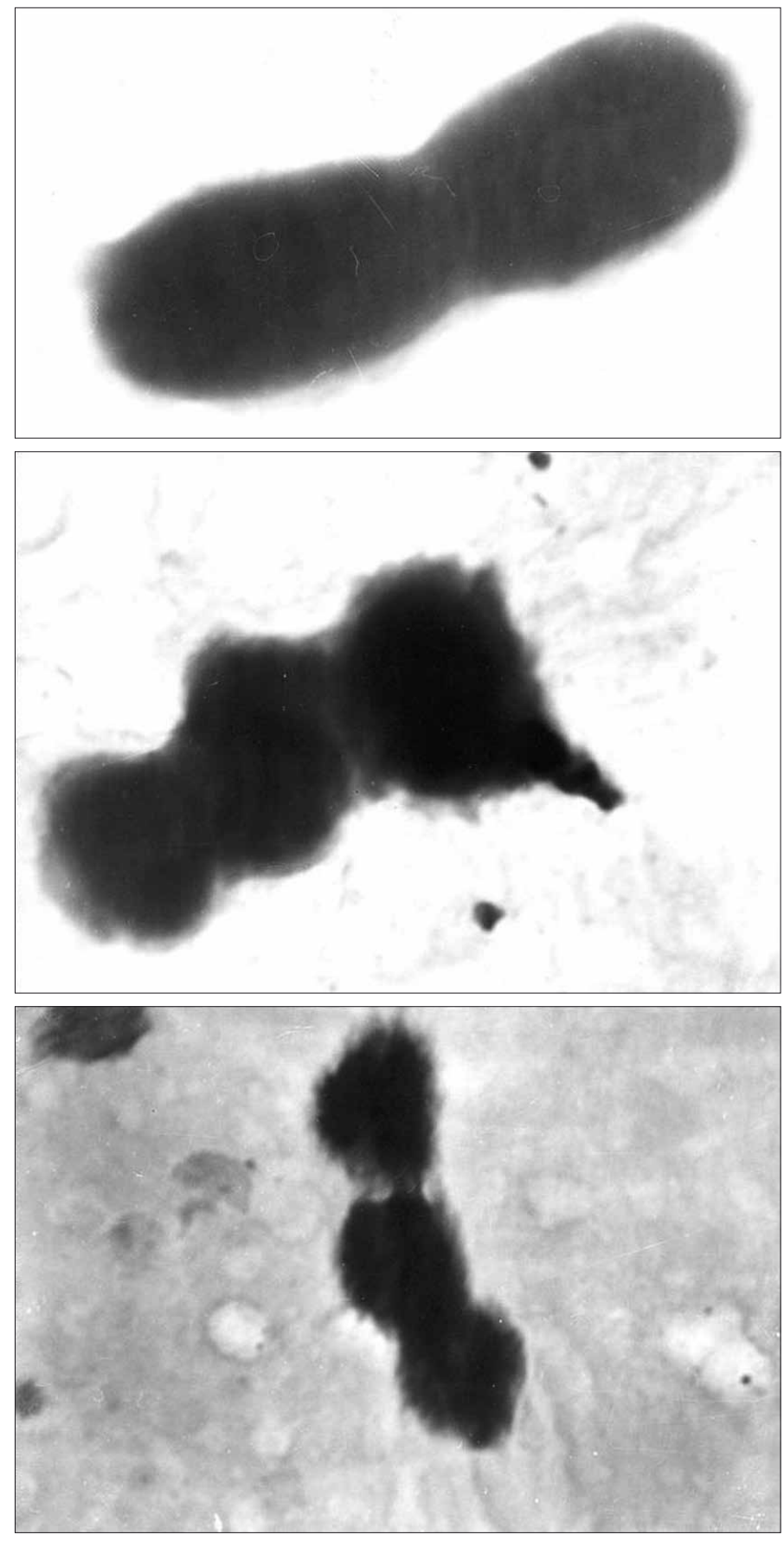

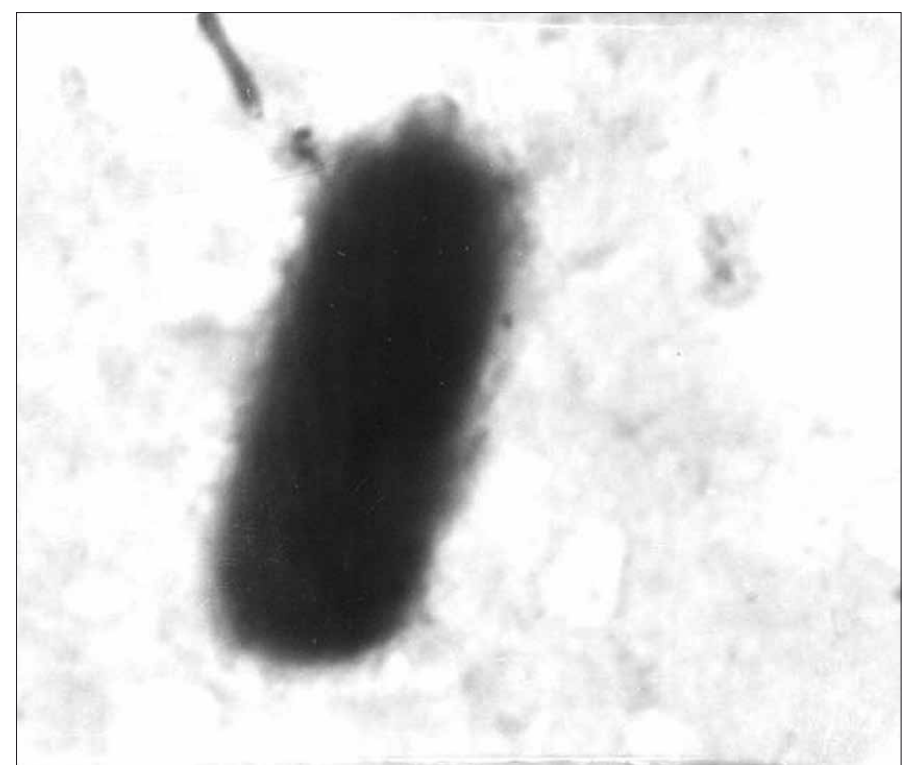

Fig. 4. Control cell of Chromohalobacter beijerinckii

bacter beijerinckii cell and cells of this bacterium subjected to a pressure of $400 \mathrm{MPa}$ for $15 \mathrm{~min}$. Such pressure treatment caused inactivation of Chromohalobacter beijerinckii, which is shown in Fig. 1. The lack
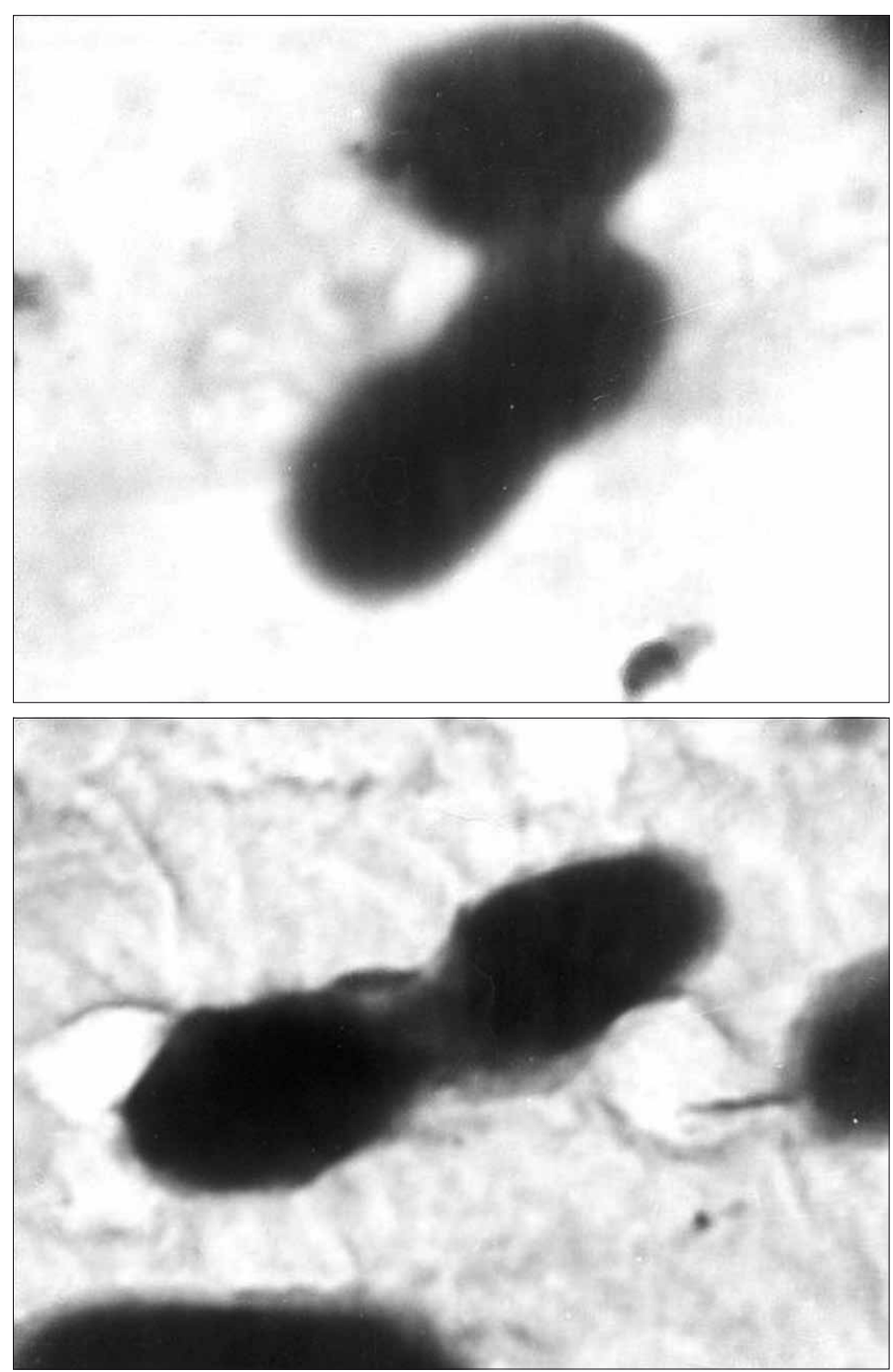

Fig. 5. Damages to Chromohalobacter beijerinckii cells caused by high pressure $\left(400 \mathrm{MPa}, 15 \mathrm{~min}, 20^{\circ} \mathrm{C}\right)$ 
of bacterial growth in the culture medium probably resulted from the damage of the cell coat and surface structure of the cell wall, which in practice could mean the loss of the colony-forming ability (18). The mechanism causing the death of microorganisms under high pressure conditions has not yet been fully explained. The differences in the sensitivity of microorganisms to high pressure treatment are explained, among others, by differences in the cell wall structure. At present, it is known that under a pressure of more than 150-200 $\mathrm{MPa}$, there may be some changes in the appearance and shape of cells, loss of the integrity of the cell wall and cell membranes, as well as changes in the protein tertiary structure. Chromohalobacter beijerinckii belongs to the extremely halophilic bacteria and does not contain mureine in its cell wall $(2,3,16)$, which may affect its sensitivity to high pressure treatment. The information presented contains introductory observations regarding morphological changes in the cells of Chromohalobacter beijerinckii subjected to high hydrostatic pressure.

To sum up the results of our study and the observations of other authors, we would like to emphasize that ultra high hydrostatic pressure can be applied to food not only to eliminate various pathogenic bacteria $(5,7$, $8,12,25,26)$, but also bacteria like Chromohalobacter beijerinckii, a non-pathogenic microorganism showing a specific enzymatic activity, such as biogenic amines production. The elimination or reduction of these bacteria in fish containing high levels of histidine seems to be particularly important from the hygienic point of view. The chemical composition of the environment in which bacteria are subjected to high pressure treatment may have a significant effect on the reduction in the number of Chromohalobacter beijerinckii. The high protein and fat content in fish may increase the resistance of these bacteria to high pressure treatment. Chromohalobacter beijerinckii belongs to bacteria with average sensitivity to high hydrostatic pressure.

\section{References}

1. Arahal D. R., Ventosa A.: The Family Halomonadaceae, [in:] M. Dworkin, S. Falkow, E. Rosenberg, K. H. Schleifer, E. Stackebrandt (eds.): The Prokaryotes: An Evolving Electronic Resource for the Microbial Community. Springer, New York, USA 2005.

2. Beutling D., Pęconek J.: Eigenschaften halophiler Bakterien isoliert von Salzheringen. Arch. Lebensmittelhyg. 1995, 46, 36-40.

3. Beutling D., Pęconek J., Stan-Lotter H.: Chromohalobacter beijerinckii: a psychrophilic, extremely halotolerant and enzymatically active microbe from salted food with the capacity for biogenic amine production. Eur. Food Res. Technol. 2009, 229, 725-730.

4. Conner A. J., Benson K. C.: Acidophilic halophilic microorganisms in fluid inclusions in halite from Lake Magic, Western Australia. Astrobiology 2013, 9, 850-860.

5.Fonberg-Broczek M., Arabas J., Kostrzewa E., Reps A., Szczawiński J., SzczepekJ., Windyga B., Porowski S.: High pressure treatment of chosen fruit, meat and cheese products - equipment, methods and results. In Proc. Foods Quality Optimization and Process Assesment, F.A.R. Oliveira and J. C. O. Oliveira, eds. CRC Press LLC, Boca Raton, London 1999, p. 281-300.

6. Fonberg-Broczek M., Sawilska-Rautenstrauch D., Windyga D., Ścieżyńska H., Jędra M., Badowski P., Urbanek-Karłowska B.: Zawartość histaminy i tyra- miny w zależności od jakości mikrobiologicznej śledzi solonych przechowywanych w różnych temperaturach. Roczn. PZH 2003, 54, 87-95.

7. Fonberg-Broczek M., Windyga B.: Zapewnienie bezpieczeństwa żywności metodą pasteryzacji wysokociśnieniowej. Bromat. Chem. Toksykol. Suplement 2005, p. 83-66.

8. Fonberg-Broczek M., Windyga B., Szczawiński J., Szczawińska M., PietrzakD., Prestamo G.: High pressure processing for food safety. Acta Biochim. Pol. 2005, 52, 721-724.

9. Hedi A., Essghaier B., Cayol J. L., Fardeau M., Sadfi N.: Prokaryotic biodiversity of halophilic microorganisms isolated from Sehline Sebkha Salt Lake (Tunisia). Afr. J. Microbiol. Res. 2014, 8, 355-367.

10. Hof T:: An investigation of the microorganisms commonly present in salted beans. Rec. Trav. Bot. Neerl. 1935, 32, 151-173.

11. Jackowska A., Szczawiński J., Pęconek J., Fonberg-Broczek M.: Possibility of Campylobacter jejuni inactivation in smoked salmon by high-pressure treatment. High Press. Res. 2008, 28, 127-132.

12. Karnop G.: Histamin in Salzsardellen. Arch. Lebensmittellhyg. 1988, 39, 67-73.

13. Karlowski K., Windyga B., Fonberg-BroczekM., Ścieżyńska H., Grochowska A., Górecka K., MroczekJ., Grochalska D., Barabasz A., Arabas J., SzczepekJ., Porowski S.: Effects of high pressure treatment on the microbiological quality, texture and colour of vacuum packed pork meat products, High Press. Res. 2002, 22, 725-732.

14. Lugue R., Bejar V., Quesada E., Martinez-Checa F., Liamas I.: Halomons ramblicola sp. nov., a moderately halophilic bacterium from Rambla Salada, a Mediterranean hypersaline rambla in south-east Spain. Int. J. Syst. Evol. Microbiol. 2012, 62, 2903-2909.

15. Pęconek $J$.: Rola niektórych grup bakterii psychrofilnych w procesie psucia się ryb. Roczn. PZH (1991), 62, 407-413.

16. PecconekJ., Beutling D.: Research on properties of halophilic bacteria isolated from salted fish. Proc. Halophiles 2001, Proc. Halophiles 2001 - International Congress on Halophilic Microorganisms. Sevilla, Spain, 23-27 Sept. 2001, p. 58.

17. Pęconek J., Beutling D.: Untersuchungen zu proteolytischen Eigenschaften halophiler Bakterien, isoliert aus Salzheringen baltischer Herkunft. Arch. Lebensmittelhyg. 1999, 50, 124-127.

18. PęconekJ., Beutling D.: Weitere Untersuchungen zu Eigenschaften halophiler, psychrotropher Bakterien, isoliert aus Salzheringen aus der Ostsee. Arch. Lebensmittelhyg. 1995, 46, 137-139.

19. Pęconek J., Beutling D., Szczawiński J.: Lipolyse halophiler Bakterien aus Ostsee-Salzheringen. Lipolytische Aktivität gegen Lebertran, Butter and Tween 80 im Laborversuch. Fleischwirtschaft 2004, 84, 117-119.

20. Pęconek J., Gruber C., Gallego V., Ventosa A., Busse H. J., Kämpfer P., Radax C., Stan-Lotter H.: Reclassification of Pseudomonas beijerinckii Hof 1935 as Chromohalobacter beijerinckii comb. nov. and emended description of the species. Int. J. Syst. Evol. Microbiol. 2006, 56, 1953-1957.

21. Pęconek J., Gruber C., Radax C., Stan-Lotter H.: Properties of strain 3b, an extremely halophilic isolate from Baltic salted herrings with similarities to Pseudomonas beijerinckii and species of the genus Chromohalobacter. Proc. Halophiles 2004 - International Congress on Halophilic Microorganisms. Ljubljana, Slovenia, 4-9 Sept. 2004, p. 120.

22. PęconekJ., Szczawiński J., Fonberg-Broczek M., Sawilska-Rautenstrauch D., Windyga B.: Rola bakterii halofilnych w dekarboksylacji histydyny w rybach solonych. Rocz. Państwowego Zakładu Higieny 1997, 48, 139-143.

23. Pietrzak D., Fonberg-Broczek M., Mucka M., Windyga B.: Effect of high pressure on the quality of cooked pork ham prepared with different levels of curing ingredients. High Press Res. 2007, 27, 27-31.

24. Szczawiński J., Klusek A., Szczawińska M. E.: Growth responses of Salmonella enteritidis subjected to heat or high pressure treatment in a laboratory medium. High Press. Res. 2009, 29, 141-149.

25. Szczawiński J., PęconekJ., Szczawińska M., Porowski S., Fonberg-Broczek M., Arabas J.: High pressure inactivation of Listeria monocytogenes in meat and meat products, [in:] Shelf life prediction for improved safety and quality of foods. Copernicus Project CIPA-CT94-0120. Copi-Print Library Building University College, Dublin 1998, 181-186.

26. Szczawiński J., Stańczak B., Pęconek J.: Survival of Enterococcus hirae in ripened cheese subjected to ultra high pressure. Pol. J. Vet. Sci. 2003, 6, 267-269.

Corresponding author: prof. dr hab. Jacek Szczawiński, ul. Nowoursynowska 159, 02-776 Warszawa, Poland; e-mail: jacek_szczawinski@sggw.pl 